\title{
Deteksi Aging pada Perempuan Berdasarkan Status Antioksidan
}

\author{
Hery Winarsi, ${ }^{1}$ Alice Yuniati, ${ }^{2}$ Agus Purwanto ${ }^{3}$ \\ ${ }^{1}$ Fakultas Kedokteran dan Ilmu-Ilmu Kesehatan, Jurusan Ilmu Gizi Universitas Soedirman \\ ${ }^{2}$ Fakultas Biologi Universitas Soedirman, ${ }^{3}$ RSUD Margono Soekarjo Purwokerto
}

\begin{abstract}
Abstrak
Aging diinisiasi oleh terakumulasinya radikal bebas. Antioksidan yang diketahui dapat mengendalikan reaktivitas radikal bebas diasumsi sebagai anti-aging. Penelitian ini bertujuan untuk mengetahui usia awal terjadi aging pada perempuan berdasarkan status antioksidan. Penelitian ini bersifat observasional analitik yang dirancang secara purposive random sampling dilakukan di Purwokerto pada tahun 2008 dengan melibatkan 34 perempuan usia balita, anak-anak, remaja, dewasa, tua dan lansia, yang sehat, dan tinggal di Purwokerto. Status antioksidan diketahui berdasarkan aktivitas enzim superoksida dismutase (SOD), katalase, dan glutation peroksidase (GSHPX) eritrosit serta kadar malondialdehid (MDA) plasma responden. Data diuji menggunakan analysis of varians (ANOVA). Status antioksidan perempuan sehat dari usia balita hingga lansia adalah prima yang ditunjukkan oleh tingginya aktivitas SOD berkisar 1.469+3,58-2.009+4,12 U/mg; katalase 20,37+0,01-31,45+0.04 UI/mg; GSH-PX 79,03+0,0-225,2+0,04 $\mu \mathrm{mol} / \mathrm{g}$ protein eritrosit; didukung oleh kadar MDA yang rendah dengan kisaran $3.134+2,56-3.185+3,06 \mathrm{pmol} / \mathrm{mL}$ plasma. Secara umum, penurunan status antioksidan terjadi pada usia dewasa (24-<45 tahun), sehingga pada usia tersebut para perempuan mulai memerlukan tambahan suplemen antioksidan guna menghambat laju proses aging dalam tubuhnya. [MKB. 2013;45(3):141-6]
\end{abstract}

Kata kunci: Aging, GSH-PX, katalase, malondialdehid, perempuan, superoksida dismutase

\section{Aging Detection in Female Based on Antioxidant Status}

\begin{abstract}
Aging is initiated by the accumulation of free radicals. Antioxidants which were known to control the reactivity of free radicals can be assumed as an anti aging. This study aimed to determine the age of the onset of aging in female based on antioxidant status. The analytical observational study with purposively random sampling design was conducted in Purwokerto in the year of 2008 with 34 females included toddlers, children, adolescents, adults, old, and elderly who were healthy, and live in Purwokerto. Antioxidant status was known by enzyme activities of superoxide dismutase (SOD), catalase, gluthathion peroxidase (GSH-PX) in the erythrocytes and malondialdehyde (MDA) levels in the plasma. Data were tested by analysis of varians (ANOVA). Antioxidant status in healthy female from toddlers to the elderly were prime as indicated by the high SOD, catalase, and GSH-PX activities that ranged 1,469+3.58-2,009+4.12 U/mg; $20.37+0.01-31.45+0.04 \mathrm{UI} / \mathrm{mg} ; 79.03+0.01-225.2+0.04 \mu \mathrm{mol} / \mathrm{g}$ protein of erythrocytes, respectively; supported by low levels of MDA that ranged from 3,134+2.56-3,185+3.06 $\mathrm{pmol} / \mathrm{mL}$ plasma. In general, the decrease in antioxidant status occurred in adults, so at that age female began to need additional antioxidant supplements in order to inhibit the rate of aging processes in the body. [MKB. 2013;45(3):141-6]
\end{abstract}

Key words: Aging, catalase, female, GSH-PX, malondialdehyde, superoxide dismutase

Korespondensi: Dr. Hery Winarsi, MS, Jurusan Ilmu Gizi, Fakultas Kedokteran dan Ilmu-ilmu Kesehatan Universitas Soedirman Jl. Suparno, Karangwangkal Purwokerto 53123, mobile 08161488133, e-mail: winarsi12@gmail.com 


\section{Pendahuluan}

Salah satu teori menyatakan bahwa aging terjadi akibat akumulasi kerusakan sel oleh karena radikal bebas. ${ }^{1}$ Radikal bebas merupakan hasil samping proses metabolisme normal yang dapat melibatkan oksigen, seperti senyawa oksigen reaktif (SOR) dan senyawa nitrogen reaktif (SNR). Senyawa radikal mengandung elektron tidak berpasangan pada kulit terluar sehingga sangat reaktif menarik elektron dari molekul di sekelilingnya untuk melengkapi kekurangan elektron di dalamnya. Akibat reaktivitasnya, molekul yang kehilangan elektron berubah menjadi radikal yang baru dan akhirnya menyebabkan kerusakan sel, gangguan fungsi sel, bahkan kematian sel. Molekul penting di dalam tubuh yang rentan dirusak oleh radikal bebas yaitu deoxyribonucleic acid (DNA), lemak, dan protein. ${ }^{2}$

Demikian pula dengan usia yang bertambah, maka banyak kerusakan sel akibat radikal bebas makin berperan mengganggu metabolisme sel, serta merangsang mutasi sel-sel, yang akhirnya menimbulkan penyakit serta kematian. ${ }^{3}$ Selain itu, radikal bebas juga merusak protein yang menjaga kelembaban, kehalusan, dan elastisitas kulit. Jaringan tubuh akan menjadi rusak akibat paparan radikal bebas di dalam jangka panjang, serta dapat menyebabkan pembentukan lekukan dan kerutan kulit yang menggambarkan aging. ${ }^{4}$ Telah diyakini bahwa radikal bebas merupakan penyebab utama aging. Perempuan umumnya lebih mengkhawatirkan aging bila dibandingkan dengan pria, ${ }^{5}$ dengan demikian untuk menghambat proses aging perempuan penting mengendalikan pembentukan radikal bebas yang dapat dilakukan dengan memperbaiki status antioksidan selular. Hingga saat ini belum ada data yang mengungkap pada usia berapa perempuan mengalami proses aging. Penelitian ini bertujuan untuk mengetahui usia berapa awal terjadinya aging pada perempuan berdasarkan status antioksidannya.

\section{Metode}

Penelitian observasional analitik ini dilakukan dengan cara purposive random sampling design. Sebanyak 34 perempuan usia balita ( $<5$ tahun), anak-anak (5-<12 tahun), remaja (12-<24 tahun), dewasa (24-<45 tahun), tua (45-<65 tahun) hingga lansia $(>65 \text { tahun })^{6}$ dilibatkan sebagai responden. Responden terpilih dalam kondisi sehat, tidak terdapat riwayat penyakit hipertensi, jantung, diabetes melitus, kanker serviks, dan kanker payudara, serta tinggal di Purwokerto dan bersedia ikut dalam penelitian.

Darah sebanyak $2 \mathrm{~mL}$ diambil menggunakan venojek mengandung ethylene diamine tetra acid (EDTA). Separasi darah dilakukan dengan sentrifugasi, kecepatan $3.000 \mathrm{rpm}$ selama 10 menit, sehingga terbentuk 2 lapisan, yaitu plasma (lapisan atas) dan granulosit (lapisan bawah). Plasma diambil menggunakan pipet pasteur lalu disimpan pada suhu $-80{ }^{\circ} \mathrm{C}$ hingga dilakukan analisis kadar malondialdehida (MDA) plasma. ${ }^{7}$ Eritrosit diisolasi dari granulosit, dengan cara dicuci mempergunakan $3 \mathrm{~mL}$ natrium chloride $(\mathrm{NaCl})$ fisiologis, kemudian dilakukan sentrifugasi dengan kecepatan $3.000 \mathrm{rpm}$ selama 10 menit. Eritrosit dicuci dengan akuabides dingin $2 \mathrm{~mL}$, lalu dibiarkan pada suhu $4{ }^{\circ} \mathrm{C}$ selama 15 menit, kemudian diresuspensi dengan bufer fosfat 0,01 $\mathrm{mmol} / \mathrm{L}, \mathrm{pH}$ 7. Eritrosit siap digunakan untuk uji aktivitas enzim superoksida dismutase (SOD), katalase, dan glutation peroksidase (GSH-PX). ${ }^{8}$ Untuk dapat mengetahui aktivitas enzim spesifik, maka kandungan protein eritrosit dapat dihitung memakai Metode Bradford. Sebelum dilakukan pengujian, eritrosit digerus, kemudian disentrifus, dan lapisan atas ditentukan aktivitas enzim.

\section{Hasil}

Secara umum aktivitas SOD perempuan usia balita, anak-anak, remaja, dewasa, tua, dan lansia

Tabel 1 Profil Responden

\begin{tabular}{|c|c|c|c|c|c|c|}
\hline \multirow{2}{*}{$\begin{array}{c}\text { Kelompok } \\
\text { Perempuan }\end{array}$} & \multirow{2}{*}{$(\mathbf{n})^{*}$} & \multirow{2}{*}{$\begin{array}{c}\text { Usia Rata-rata } \\
\text { (tahun) }\end{array}$} & \multirow{2}{*}{$\begin{array}{c}\mathrm{BMI} \\
\left(\mathbf{k g} / \mathbf{m}^{2}\right)\end{array}$} & \multicolumn{2}{|c|}{ Tekanan Darah } & \multirow{2}{*}{ Tanda Vita } \\
\hline & & & & Sistol & Diastol & \\
\hline Balita & 9 & 3,31 & 12,99 & $\mathrm{Td}$ & $\mathrm{Td}$ & Normal \\
\hline Anak-anak & 5 & 7,8 & 14,81 & $\mathrm{Td}$ & $\mathrm{Td}$ & Normal \\
\hline Remaja & 5 & 20 & 20,52 & 109 & 78 & Normal \\
\hline Dewasa & 5 & 38,8 & 25,89 & 132 & 94 & Normal \\
\hline Tua & 5 & 55,2 & 20,26 & 135 & 85 & Normal \\
\hline Lansia & 5 & 73 & 20,65 & 144 & 94 & Normal \\
\hline
\end{tabular}

$*_{\mathrm{n}}=\mathrm{jumlah}$ responden; $\mathrm{BMI}=$ body mass index; $\mathrm{Td}=$ tidak diukur 


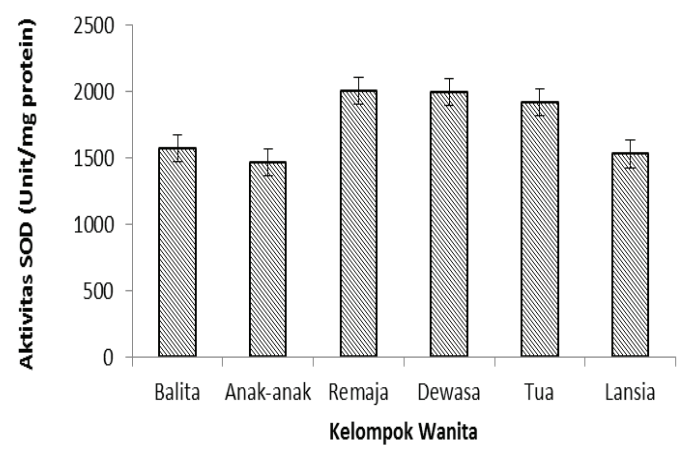

Gambar 1 Aktivitas SOD Eritrosit Wanita

meningkat signifikan $(\mathrm{p}=0,0004)$ dan aktivitas tertinggi terjadi pada usia remaja yaitu $2.009+4,12$ unit/mg protein (Gambar 1). Aktivitas SOD balita tidak berbeda dengan kelompok anak $(p=0,48)$, kelompok anak berbeda dengan kelompok remaja $(\mathrm{p}=0,04)$, sedangkan kelompok remaja, dewasa, hingga tua tidak berbeda $(\mathrm{p}=0,71)$, kemudian menurun pada masa lansia $(\mathrm{p}=0,007)$.

Hasil uji analysis of varians (ANOVA) dari kelima kelompok usia perempuan tersebut tidak menunjukkan terdapat perbedaan aktivitas katalase. Aktivitas katalase berkisar 20,02+0,01$31,45+0,04 \mathrm{UI} / \mathrm{mg}$ protein (Gambar 2).

Usia perempuan yang bertambah menurunkan aktivitas GSH-PX yang secara signifikan terjadi pada usia dewasa hingga lansia $(p=0,03)$. Pada perempuan dewasa, aktivitas GSH-PX rata-rata $183,7+0,02 \mu \mathrm{mol} / \mathrm{g}$, tetapi setelah masuk usia lansia aktivitasnya menurun hingga 79,03+0,01 $\mu \mathrm{mol} / \mathrm{g}$ (Gambar 3).

Hasil analisis sidik ragam ini menunjukkan bahwa kadar MDA plasma meningkat tetapi tidak siginifikan ( $\mathrm{p}=0,25$; Gambar 4). Kadar MDA plasma perempuan dari usia balita hingga lansia

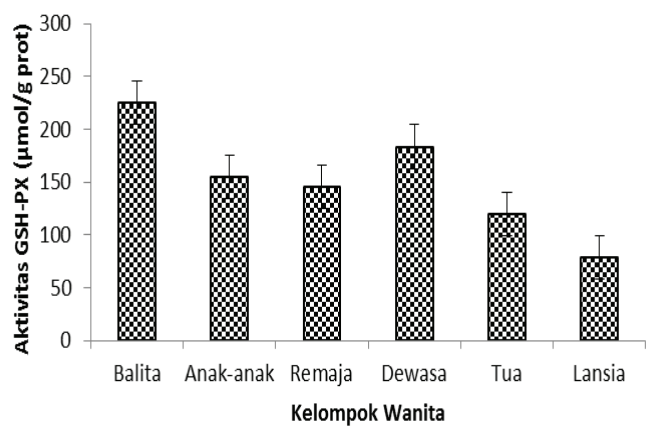

Gambar 3 Aktivitas GSH-PX Eritrosit Wanita

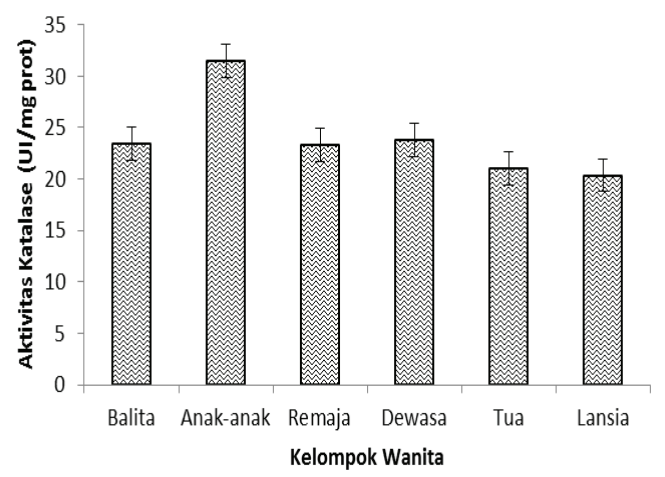

Gambar 2 Aktivitas Katalase Eritrosit Wanita

sebesar 3.134+2,56-3 dan $185+3,06 \mathrm{pmol} / \mathrm{mL}$.

\section{Pembahasan}

Berdasarkan body mass index (BMI), tekanan darah, dan tanda vital semua responden dalam kondisi sehat. Perlu disadari bahwa tubuh secara terus menerus akan menghasilkan radikal bebas, baik melalui metabolisme normal, peradangan, kekurangan gizi, maupun akibat efek lingkungan seperti polusi, ultraviolet, asap rokok, dan lainlain, ${ }^{2}$ oleh karena itu, seiring dengan usia yang bertambah, maka bertambah pula penumpukan radikal bebas dalam tubuh, hingga terjadi stres oksidatif. ${ }^{3}$ Lambat laun kondisi yang seperti ini dapat menginisiasi aging (penuaan). Beberapa peneliti telah meyakinkan bahwa aging berkaitan dengan peningkatan kejadian sejumlah kondisi degeneratif, ${ }^{9}$ antara lain penyakit Alzheimer, ${ }^{10}$ Parkinson, ${ }^{11,12}$ serta amyotrophic lateral sclerosis (ALS), aterosklerosis, dan infark miokardium. ${ }^{13}$

Untuk dapat mengetahui kondisi kesehatan responden pada level selular dilakukan pengujian

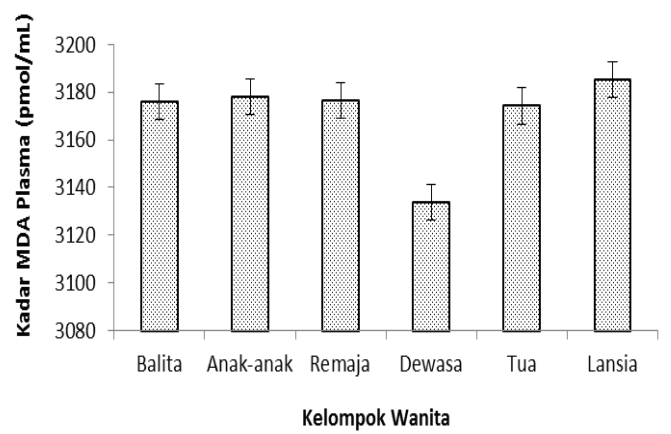

Gambar 4 Kadar MDA Plasma Wanita 
aktivitas enzim antioksidan seperti SOD, katalase, dan GSH-PX dalam eritrosit, serta kadar MDA (sebagai produk peroksidasi lipid) dalam plasma. Kerja SOD adalah menekan kerusakan oksidatif dengan cara mengkatalisis reaksi dismutasi anion superoksida $\left(\mathrm{O}_{2}{ }^{*}\right)$ menjadi $\mathrm{H}_{2} \mathrm{O}_{2}$. $\mathrm{H}_{2} \mathrm{O}_{2}$ merupakan oksidator kuat yang rentan menjadi radikal bebas, karena itu harus segera dinetralisir. Aktivitas SOD yang tinggi pada usia remaja hingga tua, merupakan bukti bahwa kadar radikal bebasnya rendah, sebaliknya penurunan aktivitas SOD pada usia lansia merupakan bukti bahwa kadar radikal bebasnya meningkat, ${ }^{3,14,15}$ bahkan diyakini bahwa kondisi seperti tersebut merupakan salah satu marker aging. Hal ini terjadi karena radikal bebas sangat reaktif menyerang membran sel termasuk sel endotel, sehingga menekan status antioksidan dan sistem imun, bahkan mempermudah terserang infeksi. Seseorang yang mengalami sakit terlihat lebih tua dibandingkan dengan usianya, karena banyak sel yang mengalami kerusakan.

Hingga sampai saat sekarang hubungan antara aktivitas SOD dan aging masih kontroversi; namun sering kali antioksidan diasumsikan sebagai antiaging, artinya aktivitas enzim antioksidan yang tinggi maka laju aging rendah. Kenyataannya, responden kelompok usia tua dengan aktivitas SOD-nya $1.917+2,4$ unit $/ \mathrm{mg}$ protein tampak lebih muda bila dibandingkan dengan perempuan penderita sindrom metabolik usia sama, dengan aktivitas SOD-nya 379,3+150 Unit/mg protein. ${ }^{8}$ Temuan ini memperjelas bahwa pada perempuan sehat, aktivitas SOD lebih tinggi dan tampak lebih muda bila dibandingkan dengan perempuan sakit yang aktivitas SOD lebih rendah. Demikian pula yang terjadi pada individu yang mengalami gangguan fungsi sel dalam jangka panjang dapat memicu berbagai jenis penyakit degeneratif dan aging. ${ }^{16}$ Temuan ini juga mendukung pernyataan bahwa dengan usia perempuan yang bertambah, maka status antioksidan menurun sebagai akibat penumpukan radikal bebas dalam tubuh. Enzim SOD akan bekerja sama dengan enzim katalase dan glutation peroksidase untuk dapat menangkal reaktivitas radikal bebas dalam tubuh.

Katalase merupakan enzim yang mempunyai heme dan dapat mengkatalis perubahan $\mathrm{H}_{2} \mathrm{O}_{2}$ menjadi air dan oksigen. Enzim ini aktif dalam mitokondria, sitoplasma dan juga pada peroksisom bermacam-macam sel. ${ }^{2}$ Dikatakan pula bahwa katalase sebagai enzim peroksidasi khusus dalam reaksi dekomposisi $\mathrm{H}_{2} \mathrm{O}_{2}$ menjadi oksigen dan air, dengan cara mengoksidasi 1 molekul $\mathrm{H}_{2} \mathrm{O}_{2}$ menjadi $\mathrm{O}_{2}$, kemudian secara simultan mereduksi molekul $\mathrm{H}_{2} \mathrm{O}_{2}$ kedua menjadi air. Reaksi enzim ini dapat berjalan bila terdapat senyawa pemberi ion hidrogen $\left(\mathrm{AH}_{2}\right)$ seperti metanol, etanol, dan formiat. Peran katalase dalam mengkatalisis $\mathrm{H}_{2} \mathrm{O}_{2}$ relatif lebih kecil dibandingkan dengan kecepatan pembentukannya. Sel yang mengandung sedikit katalase sangat rentan pada serangan peroksidasi. Katalase juga berperan penting dalam mekanisme pertahanan eritrosit terhadap oksidator $\mathrm{H}_{2} \mathrm{O}_{2}$.

Tidak terdapat perbedaan antara kelompok tersebut mungkin karena peran enzim katalase dalam mengubah $\mathrm{H}_{2} \mathrm{O}_{2}$ menjadi $\mathrm{O}_{2}$ relatif kecil dibandingkan dengan kerja enzim GSH-PX yang keberadaannya relatif stabil dan tidak fluktuatif. Meskipun demikian, responden pada kelompok tua (aktivitas katalase $21,02+0,01 \mathrm{UI} / \mathrm{mg}$ ) terlihat lebih muda bila dibandingkan dengan perempuan penderita sindrom metabolik usia sama (aktivitas katalase $6,42+2 \mathrm{UI} / \mathrm{mg}){ }^{8}$ Umumnya, aktivitas enzim antioksidan ini diperbaiki dengan produk yang kaya antioksidan, akan tetapi pemberian suplemen antioksidan tidak khusus menginduksi kerja enzim katalase ini, melainkan kerja enzim antioksidan secara total, baik SOD, katalase, maupun GSH-PX.

Penurunan aktivitas GSH-PX dalam eritrosit perempuan usia balita hingga lansia mungkin disebabkan oleh hal-hal berikut: pertama, dengan usia seseorang yang bertambah, maka sel tubuh mengalami atrofi. ${ }^{17}$ Ketika sel atrofi, maka semua organel serta fungsi sebagai pensekresi enzim tidak optimal, demikian pula aktivitas enzim yang disekresikan juga menurun. Kedua, kemungkinan karena kekurangan selenium, suatu mikromineral yang penting dalam aktivitas GSH-PX. Winarsi dkk. $^{3}$ meyakinkan bahwa usia seseorang yang bertambah, maka sel tubuh mengalami degenerasi, metabolisme terganggu, demikian pula status antioksidan juga mengalami penurunan, karena itu aktivitas GSH-PX menurun signifikan pada perempuan usia lansia. Berdasarkan temuan ini sudah selayaknya para perempuan mendapatkan asupan kaya antioksidan sejak usia tua (45 tahun). Malondialdehid adalah senyawa dialdehid yang merupakan produk akhir dari peroksidasi lipid di dalam tubuh. Senyawa ini juga dapat dihasilkan oleh radikal bebas melalui suatu reaksi ionisasi di dalam tubuh dan produk samping biosintesis prostaglandin sebagai produk akhir dari oksidasi membran lipid. Malondialdehid terbentuk akibat degradasi radikal bebas $\mathrm{OH}$ terhadap asam lemak tidak jenuh, yang diubah menjadi radikal bebas yang sangat reaktif, ${ }^{14}$ maka pengukuran MDA sering digunakan sebagai indikator peroksidasi lipid jaringan. ${ }^{18}$ Kadar MDA yang tinggi akan mencerminkan proses oksidasi lipid membran sel, ${ }^{7,19}$ dan sebaliknya kadar MDA yang rendah membuktikan aktivitas enzim antioksidan tinggi atau status antioksidan. ${ }^{14}$

Pada beberapa spesies, aging terjadi akibat penurununan status antioksidan yang kemudian menghambat progresivitas pertahanan tubuh. ${ }^{20}$ 
Untuk memperbaiki kondisi tersebut di atas, perlu diimbangi dengan asupan suplemen antioksidan. Hulbert dkk. ${ }^{21}$ menyatakan suplemen antioksidan dapat mencegah stres oksidatif yang berasal dari eksogen ataupun karena kondisi patologis.

Berdasarkan aktivitas enzim SOD, katalase, GSH-PX eritrosit, dan juga kadar MDA plasma menunjukkan status antioksidan para perempuan tersebut mengalami penurunan sejak usia dewasa, karena itu pemberian suplemen antioksidan lebih tepat diawali pada usia dewasa (38,8 tahun). Diet kaya antioksidan berdampak positif pada aktivitas enzim selular, sebaliknya diet miskin antioksidan akan memudahkan seseorang terserang penyakit, dan tampak lebih tua dibandingkan dengan usia sebenarnya (biologis).

Tubuh dapat menghasilkan senyawa radikal bebas melalui proses fosforilasi dalammitokondria yang menyebabkan 1 molekul $\mathrm{O}_{2}$ tereduksi oleh 4 elektron bersama ion $\mathrm{H}+$. Pembentukan senyawa radikal bebas tersebut merupakan inisiator proses peroksidasi lipid atau MDA penyebab kerusakan jaringan tubuh. Perempuan premenopause usia sama dengan kelompok usia tua, ternyata kadar MDA plasma sebesar $3.489-3.692 \mathrm{pmol} / \mathrm{mL}^{14}$ lebih tinggi daripada perempuan sehat.

Keadaan antioksidan perempuan yang sehat dari usia balita sampai usia lansia adalah prima ditunjukkan oleh aktivitas SOD yang tinggi sebesar $1.469+3,58-2.009+4,12 \mathrm{U} / \mathrm{mg}$, katalase $20,37+0,01-31,45+0,04 \mathrm{UI} / \mathrm{mg}$, dan juga GSHPX 79,03+0,01-225,2+0,04 $\mu \mathrm{mol} / \mathrm{g}$ protein eritrosit didukung oleh kadar MDA yang rendah dengan kisaran 3.134+2,56-3.185+3,06 pmol/ $\mathrm{mL}$. Penurunan status antioksidan pada usia dewasa menunjukkan bahwa pada usia tersebut proses aging sudah mulai berlangsung, sehingga para perempuan mulai memerlukan tambahan suplemen antioksidan untuk dapat menghambat laju dalam tubuhnya. Dengan diketahui usia awal terjadi proses aging ini, para perempuan dapat mempersiapkan diri agar terhindar dari berbagai penyakit degeneratif secara dini.

\section{Ucapan Terima Kasih}

Ucapan terima kasih ditujukan kepada Direktorat Jenderal (Dirjen) Pendidikan Tinggi, Kementerian Pendidikan Nasional atas pendanaan penelitian ini melalui Proyek Fundamental, No. 015/SP2H/ PP/DP2M/III/2008 Tanggal 2 Maret 2008.

\section{Daftar Pustaka}

1. Capel F, Rimbert V, Lioger D, Diot A, Rousset P, Patureau MP, dkk. Due to reverse electron transfer, mitochondrial $\mathrm{H}_{2} \mathrm{O}_{2}$ release increases with age in human vastus lateralis muscle although oxidative capacity is preserved. Mech Ageing Develop. 2005;126(4):505-11.

2. Krajčovičová-Kudláčková $M$, Dušinská $M$, Valachovičová M, Blažíček P, Pauková V. Products of DNA, protein and lipid oxidative damage in relation to vitamin C plasma concentration. Physiol Res. 2006;55(1):22731.

3. Winarsi H, Muchtadi D, Zakaria FR, Purwanto A. Kajian tentang wanita perimenopause di Purwokerto dan beberapa permasalahan dalam sistem imunnya. Maj Obstet Ginekol Indones. 2005;29(3): 177-83.

4. Wei Y-H, Lee H-C. Oxidative stress, mitochondrial DNA mutation, and impairment of antioxidant enzymes in aging. Exp Biol Med. 2002;227(9):671-82.

5. Petry NM. A comparison of young, middleaged, and older adult treatment-seeking pathological gamblers. Gerontologist. 2002;42(1):92-9.

6. Laporan Riset Kesehatan Dasar 2010. (diunduh 8 November 2012). Tersedia dari: http://www.litbang.depkes.go.id

7. Winarsi H, Muchtadi D, Zakaria FR, Purwanto A. Respons hormonal-imunitas wanita premenopause yang diintervensi minuman fungsional berbasis susu skim yang disuplementasi dengan isoflavon kedelai dan Zn sulfat. J Teknol dan Industri Pangan. 2004;15(1):47-53.

8. Winarsi $\mathrm{H}$, Wijayanti SPM, Purwanto A. Aktivitas enzim SOD, katalase, dan glutation peroksidase wanita penderita sindrom metabolik. MKB. 2012;44(1):7-12.

9. Mcgeer PL, Mcgeer EG. Inflammation and the degenerative diseases of aging. Ann N Y Acad Sci. 2004;1035(1):104-16.

10. Mcgeer EG, Mcgeer PL. Inflammatory processes in Alzheimer's disease. Progr Neuropsychopharmacol Biol Psychiatry. 2003;27(5):741-9.

11. Mcgeer PL, Mcgeer EG. Inflammation and neurodegeneration in Parkinson's disease. Parkinsonism Relat Disord. 2004;10(Suppl 1):S3-7.

12. Thomas M, Le WD, Jankovic J. Minocycline and other tetracycline derivatives: a neuroprotective strategy in Parkinson's disease and Huntington's disease. Clin Neuropharmacol. 2003;26(1):18-23.

13. Mcgeer PL, Mcgeer EG. Inflammatory processes in amyotrophic lateral sclerosis. Muscle Nerve. 2002;26(4):459-70.

14. Winarsi H, Muchtadi D, Zakaria FR, Purwantara B. Status antioksidan wanita 
premenopause yang diberi minuman suplemen "Susumeno". Seminar Nasional PATPI. Yogyakarta. 22-23 Juli 2003.

15. Winarsi H, Hernayanti, Purwanto A, Sukanto. Profil dan status antioksidan wanita penderita candidiasis di Purwokerto. M Med Indones. 2006;41(3):108-12.

16. Kregel KC, Zhang HJ. An integrated view of oxidative stress in aging: basic mechanisms, functional effects, and pathological considerations. Am J Physiol Regul Integr Comp Physiol. 2007;292(1):R18-36.

17. Dirks-Naylor AJ, Lennon-Edwards S. Cellular and molecular mechanisms of apoptosis in age-related muscle atrophy. Curr Aging Sci. 2011;4(3):269-78.

18. Rukmini MS, D'Souza B, D'Souza V.
Superoxide dismutase and catalase activities and their correlation with malondialdehyde in schizophrenic patients. Indian J Clin Biochem. 2004;19(2):114-8.

19. Gupta M, Chari S. Proxidant and antioxidant status in patients of type II diabetes mellitus with IHD. Indian J Clin Biochem. 2006;21(2):118-22.

20. Linnane AW, Kios M, Vitetta L. Coenzyme Q 10 - its role as a prooxidant in the formation of superoxide anion/hydrogen peroxide and the regulation of the metabolome. Mitochondrion. 2007;7(Suppl):S51-61.

21. Hulbert AJ. Metabolism and longevity: is there a role for membrane fatty acids? Integr Comp Biol. 2010;50(5):808-17. 